\title{
Mâder-i Mevlânâ Mümine Hatun'a Yazılan Manzumeler
}

\author{
Dr. Öğr.Üyesi Zeynep Koyuncu \\ Karamanoğlu Mehmetbey Üniversitesi, Edebiyat Fakültesi \\ Türk Dili ve Edebiyatı Bölümü \\ zeynepkoyuncu@kmu.edu.tr
}

Öz

Hz. Mevlânâ (ö. 1273) ve eserleri Osmanlı toplumuna derinden tesir etmiş, bu etki klasik Türk edebiyatına da yansımış, Mevlevî olsun ya da olmasın birçok divan şairi eserlerini Mevlevîlik unsurları ile süslemiştir. Bunun yanı sıra Mevlânâ için methiyeler yazılmış, bu şiirlerde Mevlânâ'nın yakın çevresi ve aile fertlerinden de bahsedilmiştir. Mevlevî şairler Mevlânâ'nın annesi Mümine Hatun'u tıpkı Mevlânâ'yı andıkları gibi anıp övmüş, Mâder-i Mevlânâ'ya hürmetlerini şiirle ifade etmişlerdir. Mevlevî şeyh ve edibi Ahmet Midhat Beytur (ö. 1971) Mümine Hatun için bir kıta yazmış, son dönem Mevlevî şeyh ve şairlerinden Ahmed Remzi Akyürek (ö. 1944) Bir Günlük Karaman Seyahatnamesi içinde geçen beş beyitlik bir tegazzülü Karaman Mevlevîhanesi'ni ziyareti esnasında Mâder-i Mevlânâ'nın manevi huzuruna sunmuştur. Zira Mevlevî adabına göre bir "berg-i sebz" ile de olsa hediye vermek gerekir. Mevlevîlikte kutsal sayılan 9 ve 18 sayıları hediyeleşirken de geçerli olmuştur. Mâder-i Mevlânâ için 18 beyitten oluşan bir kaside kim olduğunu tespit edilemeyen Gâlib (ö. ?) mahlaslı Mevlevî bir şaire aittir. Gâlib'in talik hatlı levha şeklindeki kasidesini görüp çok beğenen Hattat Giritli Şükrü (ö. ?) önce bu kasidenin sonuna nesih hatla 4 beyit eklemiş, ardından kendisi de 19 beyitlik nesih hatlı ayrı bir kaside yazmıştır. $\mathrm{Bu}$ levha günümüzde Karaman Mevlevîhânesi'ndedir. Eldeki çalışmada Mâder-i Mevlânâ hakkında kaynaklarda yer alan kısıtlı bilgi verildikten sonra onun için yazılmış dört manzume bir araya getirilmiştir. İncelenen şiirlerin tamamında Mevlânâ'nın annesinin çeşitli sıfatlarla övüldüğü, annelik vasfı ve dinî unsurlar ile kendisinden himmet, yardım, merhamet istendiği görülmüştür.

Anahtar Kelimeler: Mâder-i Mevlânâ, Mümine Sultan, manzume, methiye.

\section{Poems Written For Mâder-i Mevlânâ Mümine Hatun}

\begin{abstract}
Hz. Mevlânâ (d. 1273) and his works deeply influenced the Ottoman society. This effect was reflected in classical Turkish literature and many Dîvân poets decorated their works with Mevlevî elements whether they were Mevlevî or not. Eulogies were written for Mevlânâ and the close circle of Mevlânâ. His family members were also mentioned in those poems. Mevlevî poets commemorated and praised Mümine Hatun, the mother of Mevlânâ, just like they commemorated him and they expressed their respect to Mâder-i Mevlânâ in poetry. Ahmet Midhat Beytur (d. 1971), a Mevlevî sheikh and scholar, wrote a stanza for
\end{abstract}


Mümine Hatun. Ahmed Remzi Akyürek (d. 1944), one of the last-period Mevlevî sheikhs and poets, presented a five-couplet tegazzul from A Day-Long Karaman Travel Book to the special presence of Mâder-i Mevlânâ during his visit to the Karaman Mevlevî Lodge. According to Mevlevî manners, it is necessary to give a gift, albeit with a "berg-i sebz". Numbers 9 and 18 considered sacred in Mevleviyeh were also valid when giving a present. An 18-couplet euology written for Mâder-i Mevlânâ belongs to a Mevlevî poet, who has a pseudonym as Gâlib (d. ?), who couldn't be identified. Calligrapher Şükrü from Crete (d. ?), who saw and admired the eulogy of Gâlib that was understood to be a plate with talik calligraphy, first added 4 couplets with naskh calligraphy to the end of this eulogy, and then wrote himself a separate 19-couplet eulogy. This plate is now in the Karaman Mevlevî Lodge. After limited information in the sources about Mâder-i Mevlânâ was given in the current study, four poems written for Mümine Hatun, the mother of Mevlânâ, were brought together. In all of the poems reviewed, it was seen that the mother of Mevlânâ was praised with various attributes, and she was asked for help, compassion and mercy with the qualities of motherhood and religious elements.

Keywords: Mâder-i Mevlânâ, Mümine Sultan, poem, eulogy. 


\section{GİRIŞ}

Mevlevîlik tarikatında yol büyüklerinin kabirleri başında anılması, şeyh ve büyüklerin dolaşılarak gönüllerinin alınması, bu ziyaretler ile manen zenginlik kazanmayı amaçlama, dervişlerin kendi aralarında muhabbeti canlı tutma amacı ile görüşmeleri gibi alışkanlıklar vardır. Kabir ziyaretlerinde bulunarak tefekkür etmek ve âhirete hazırlanmak Hz. Peygamber'in tavsiyelerindendir. Mevlevîler Mevlevîliğin pîri Mevlânâ ve onun yolunu genişleten güzide evlatlarının, din ve tasavvuf büyüklerinin ruhlarına fatihalar okumak, o mübareklerin makamlarında yüce Allah'a dua ve niyazlarda bulunmak, bu vesileyle huzur bulmak, manevî feyiz ve güzelliklere erişebilmek için türbe ve kabir ziyaretlerinde bulunurlar (Top, 2007, s. 57-58). Bu sebeple Karaman Mevlevîhânesi yüzyıllardır Mevlevîlerin mukaddesatı arasında Mevlânâ dergâhından sonra en önemli mekândır ve bu özel zaviyeye gelenlerin eli boş olmamıştır. "Tekkeye boş giren boş çıkar." tabiri ile ziyarete gidenden bir yeşil yaprak kadar da olsa yardım beklenirdi (Top, 2007, s. 182). Hediye kişinin gücü miktarınca olduğundan Mevlevî şairlerin Mâder-i Mevlânâ'ya tazim ve hürmetleri şiir ile olmuştur. Bu makalede A. Midhat Beytur, A. Remzi Akyürek, Gâlib ve Hattat Giritli Şükrü tarafından Mümine Hatun için kaleme alınan manzumelerin metinleri verilip, bu metinler muhtevasına göre incelendi. Bundan önce literatürde Mümine Hatun ile ilgili yer alan sınırlı bilgi değerlendirilmiştir.

\section{Mâder-i Mevlânâ “Mümine Sultan”}

Mevlânâ'nın annesi Mümine Hatun'a Pehlevice olan “ana, anne” anlamındaki mâder kelimesi ile terkip yapılarak "Mâder-i Sultan" yahut "Mâder Sultan” denilirdi (Gölpınarlı, 2006, s. 307). "Mâder-i Mevlânâ" Mevlânâ'nın annesi anlamına gelir. Mevlevîler, Mümine Hatun'u Mâder-i Mevlânâ, Mâder Sultan, Valide Sultan gibi tazim ifadeleri ile de anarlar.

Mümine Hatun hakkında bilgi oldukça azdır. Bugün Afganistan topraklarında bulunan Belh şehrinde evlenerek eşi ile Horasan, ardından da Anadolu'ya geldiği tüm kaynaklarda ittifaken yer alır. Tespit edilebilen menkibevî bilgilerden ilki Mevlânâ'nın annesinin şeceresinin Hz. Ebubekir'e dayandığı ve Mümine Hatun'un küçük bir çocukken Mevlânâ'nın elinden tutup onu babasının kütüphanesine getirdiği ve "Beni babana bu kitaplar yüzünden verdiler."1 dediğidir (Top, 2007, s. 29). İkincisi Evliya Çelebi'nin Seyahatnâmesi'nde geçer. H. 623 (1226) yılında Sultan Veled'in rüyasında büyük annesi Mümine Hatun'un kendisine "Yetiş ey oğul! Hâlet-i nez'deyim (ölmek üzereyim), beni defneyle." demesi üzerine Sultan Veled uyanıp yolları aşarak Karaman'da (Lârende) olan babaannesinin son nefesine yetişir ve onu Karaman Mevlevîhânesine defnedip Konya'ya döner (Evliya Çelebi, 2012, s. 35). Mevlevîlik tarihine ait kaynaklarda Sultan Veled'in doğum tarihi H. 623 (1226) olarak verildiğinden bu rivayetteki tarihin doğru olmadı̆̆ı anlaşılabilir.

Mevlevîlik tarihi üzerine yapılan çalışmalardan yalnızca Mecmuatü't-Tevarihi'lMevlevîye'de önemli bilgi ve tarihlere ulaşılmıştır. Sahih Ahmed Dede'nin (ö. 1813) Mevlevîlerin tarihini anlatan Mecmuatü't-Tevarihi'l-Mevlevîye adlı eserinde Mevlânâ'nın annesi Mümine Hatun'un yaşı, evliliği, doğum yaptı̆̆ı tarihler, çocuklarının isimleri ve kendi vefat tarihi gibi şu önemli bilgiler verilmektedir:

${ }^{1}$ Aynı ifadenin farklı bir rivayeti şöyledir: Horasan ülkesi padişahı Alaaddin Muhammed Hârizmşah'ın kızı, (Mevlânâ'nın babaannesi) on iki yaşında babasını kaybeden oğlu Bahâeddin-i Veled'i ellerinden tutarak eşi Hüseyin el-Hatibi'nin kütüphanesine götürmüss: "Beni babana bu eserler yüzünden verdiler. $O$ bu eserleri okumakla dünya ve mana ilimlerini öğrenmiş, İslâm âlemindeki müstesna yerini almıştır." diyerek oğlunu ilme teşvik etmiş ve "Sultanü'l-ulemâ" olarak anılmasına vesile olmuştur (Çelebi, 2001, s. 30). 
Bahaeddin Veled 42, Sultan Rukneddin Muhammed Ferhunde Şah'ın kızı Mümine Sultan 15 yaşında iken H. 585 (1189) yılında Belh'te evlenirler. Kızları Mevlânâ'nın ablası hemşire-i Mevlânâ- Fatıma Hatun H. 590 (1193) senesinde Belh'te doğar, (ailesinin göçe karar verip hazırlıklara başladığı H. 608 (1211) tarihinde 18 yaşındadır. Belh müftüsü ile evli olan Fatıma Hatun 19 yaşında vefat eder.) Mevlânâ'nın ağabeyi Muhammed Alaaddin Efendi H. 602 (1205) senesinde babası 59 annesi 32 yaşında iken dünyaya gelir. Mevlânâ Celaleddin H. 604 (1207) senesinin mâh-1 Rebiü'l-evvvelin 6. Leyletü'l-isneyn nısfında annesi 34 yaşında iken Belh'te doğar. H. 617 (1220) senesinde Erzincan'dan ayrılıp Karaman (Larende) kasabası'a yerleştiklerinde Valide Sultan Mümine Hatun 47, evlatları Bahaeddin 16, Celaleddin 13 yaşındadır. Mümine Hatun'un vefat tarihi eserde "İntikâl-i Vâlide Sultan" başlı̆̆ı ile verilir. Bu bilgiye göre Mevlânâ'nın annesi H. 621 (1224) tarihinde 51 yaşında iken Saferu'l-hayrda Larende kasabasında vefat eder, orada dershane içine defnolunur (Sahih Ahmed Dede, 2003, s. 127-145). Mevlânâ'nın annesinin vefat tarihini farklı nakleden kaynaklar da bulunmaktadır. Şefik Can bir delil göstermeksizin Mevlânâ'nın 1225 senesinde Gevher Hatun ile evliliğinden kısa bir süre sonra annesini kaybettiğini belirtir (Can, 1995, s. 37).

Gülcan, Mümine Hatun'un, Belh Emiri Sultan Rukneddin'in kızı olup Oğuzların Beğdili boyuna mensup olduğunu, soyunun Hz. Ebubekir'e dayandığı ileri sürer ve bu kişinin Bekir veya Ebubekir adlı başka bir İslam büyüğü olma ihtimalinden bahseder (1975, s. 2-4).

Annelerin yeri Türk-İslam örfünde her zaman üstün olduğundan Mevlânâ'nın annesi de Mevlevîler için çok muhterem ve değerlidir. Kıymetli bir din âlimi ve mutasavvıfını dünyaya getirip yetiştiren Mümine Hatun'a Osmanlı padişahlarının özel bir önem verdiği ve bu sebeple kabrin bulunduğu Karaman Mevlevîhânesi'ni koruyup kolladıkları bilinir. Veled Çelebi'nin (İzbudak) müracaatı üzerine Sultan Mehmed Reşad tarafından 19151916'da Mâder-i Mevlânâ'nın sandukası için musanna pûşîde ile yeşil kadife perdeler gönderilmiştir, sanduka rengârenk kumaşlarla örtülüdür (Tanrıkorur, 2001, s. 448; Gülcan, 1975, s. 2-4). İ. Hakkı Konyalı, Sultan Reşad'ın Mâder Sultan ve Mehmet Alaeddin Çelebi'nin sandukaları üzerine Kâbe örtüsü gönderdiğini belirtir (1967, s. 241). Günümüzde kilitli olarak muhafaza edilen bu şebekede yeşil örtünün altında işlemesiz bir sanduka bulunur. Mahfazanın son durumu² anlatılanlardan farklıdır.

\footnotetext{
${ }^{2}$ Kaynaklarda bahsedilen yeşil kadife perdeler, Kâbe örtüsü, rengarenk örtü ve V. Mehmed'in hediye ettiği puşide kayıptır. Karaman Müzesi, Konya Vakıflar Müdürlüğü ve Müzeler Müdürlüğü, Konya Mevlânâ Müzesi arşivlerinde bu eşyaların ya da matbah eşyalarının kayıtlarının olmadığı bilgisine ulaşıldı. Mevlânâ Celaleddin'in 22. kuşak torunu Esin Çelebi Bayru Karaman'ı ziyareti esnasında söz konusu kıymetli puşide ve örtülerin çalınmış olabileceği bilgisine ilaveten, şu anki döşemeyi bizzat yaptığını ve aşağıda vasıfları sayılan örtünün de kendisi tarafından serildiğini anlattı. Bayru, babasının hattat Hamid Aytaç'a "Cennet annelerin ayağı altındadır." anlamına gelen "el cennetu tahte akdâmu'l-ummuhat" hadisinin levhasını yazdırdığını, bu eserin 1996 ya da 1997'de Karaman Mevlevîhanesi'nden çalındığını, 15 yıl sonra Hamid'in bir talebesi hocasının yazdığı kalıbı bulunca bu kez kendisinin levhayı yazdırıp tekkeye hediye ettiğini, ikinci levhanın daha aynı akibete uğradığını ifade etmiştir. (E. Bayru, kişisel iletişim, 27 Nisan 2019).

Kabr-i şerifin sanduka dışındaki zemini camiin halıfleks döşeme halısı ile kaplıdır. Halıfleksin üstünde sandukayı ve yerleri de kaplayan yeşil kadife kumaş bulunur, kadife kumaşın üstünde fotoğraflanan örtü serilidir. Örtü, V. Mehmed tarafından hediye edilecek klasik Osmanlı tarzı bir puşide değildir (A. Özkan, kişisel iletişim, 1 Mayıs 2019). Çift yönlü olmakla birlikte daha sonra iç dikiş yardımı ile birleştirilen $198 \times 256 \mathrm{~cm}$, dikdörtgen görünümlü örtünün içindeki 43x124 cm'lik yazı bölümü düz işlemesiz bırakılmıştır (M. Konuk, kişisel iletişim, 22 Şubat 2019). Uzun kenarlarında paralel olarak talik yazı ile "Hazret-i Mevlânâ Celâleddin-i Rûmî Radıyallahu Teâlâ Anhu/ Mukaddime min: El Hankah El-kadiriyye Er-rezakiyye Sidre-i şerîf/Medine: Dire İsmail Han El-Bakistan" ifadesi
} 


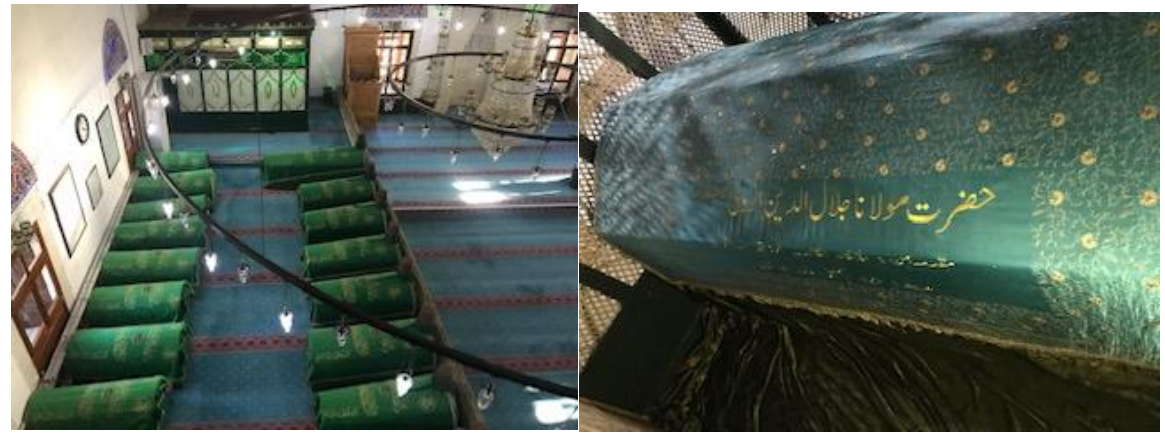

Foto 1: Valide Sultan'ın Mahfazalı Kabri, Örtüsü ve Diğer Sandukalar. (Z. K. 2019 Nisan)

\section{Hediyenin Nazım Hali: Methiye}

Mevlânâ Celaleddin Rûmî eserleri ile divan şiirine kaynaklık etmiş, şiiri ile irşat etmeyi benimsemiştir. Onun izini takip eden Mevlevî şairler de kendileri bende, köle olarak nitelemiş ve Mevlânâ'ya hizmeti yine şiirle yapmışlardır. Kendine özgü söz varlığ1 ve düşünce dünyası olan Mevlânâ methiyeleri divan şiirinde başlı başına bir kol teşkil edecek kadar çok sayıdadır (Aça vd., 2011, s.362). Mevlânâ'ya methiyeler yazılırken, yakın çevresi ve aile fertleri de bu ilgiye mazhar olmuşlardır. Şems-i Tebrîzî, Hüsameddin Çelebi, Sultan Veled, Âteşbâz-ı Velî gibi yol büyüklerinin isimleri de şiirlerde anılmıştır. Son dönem Mevlevî şairlerinden Arif Nihat Asya'nın "Aile"3 adını vermiş olduğu rubaisinde Mevlânâ'nın aile fertlerinden ilk eşi Gevher, ikinci eşi Kerrâ ve annesi Mümine Hatun'un isimleri geçer. Bu rubainin devamı niteliği taşıyan "Sesler"adlı rubaisinde ise aile fertleri konuşturulur. Asya "Karaman" adlı rubaisinde Mevlânâ'nın yeşil kubbesi ile annesi Mümine Hatun'un defnedildiği Karaman Mevlevîhanesi'nin benzerliğinden ve ziyarete gelenlerin Mâder-i Mevlânâ'ya sessizce Fâtiha göndermesinden bahsetmiştir.

Benzer rengiyle Kubbe-i Hadrâ'ya:

Derler "Karaman" bu yemyeşil dünyâya...

Her yolcu sükût...Her nefes, sessizce,

Bir Fâtiha'dır Mâder-i Mevlânâ'ya. (Asya, 1967, s. 148)

Osmanlı Şiirinde Mevlânâ Övgüleri ve Mevlevîlik Unsurları' nda (Mermer, vd., 2009) yer alan "yâ Hazret-i Mevlânâ" redifli bazı gazel ve kasideler" ile makalede işlenen iki kaside arasında iç ve dış yapı açısından benzerlikler dikkat çekicidir. Vezinler, musammat yapı, hitap üslubu ve övgü kelimeleri bakımından anne Mümine Hatun'a yazılan methiyeler Mevlânâ methiyelerinden mülhem gibidir. Mevlânâ methiyeleri yazan şairler kendilerini gedâ ve tekkenin kapısında köpek, memduhlarını sultan ve her türlü ikram sahibi olarak nitelemişlerdir. Bu benzetmeler Mümine Hatun'a yazılan methiyelerde de kullanılmıştır.

Asşıklara sultânsın âriflere bürhânsın

Dil derdine dermânsın yâ Hazret-i Mevlânâ (Mermer vd., 2008, s.126)

yazılmıştır. Yazı Türkçe olarak, “Mevlânâ Celâleddin-i Rûmî -Yüce Allah ondan razı olsun- Sidre-i Şerif elkadiriyye er-rezakiyye Hankah'ından takdim edilmiştir. Şehir Dera İsmail Han, Pakistan" anlamına gelir.

${ }^{3}$ Aile ve Sesler rubaileri için bk. (Aktaş, 2008, s. 52-53).

${ }^{4}$ bk. (Mermer vd., 2008, s.114-128).

SEFAD, 2021; (45): 253-270 
Âşıklara rehber, gönül mülküne sultan, velilik kutbu, gönül sırrına mahrem gibi benzer kelimeleri Gâlib de Mümine Hatun için kullanmıştır.

\section{Âşıklara rehbersin sâdıklara yâversin}

Dil mülkine sultânsin ey Mâder-i Mevlânâ

Makalede derlenen dört manzumede Mümine Hatun da tıpkı Mevlânâ gibi övülmüş, kendisinden yardım ve himmet istenmiştir. Mâder-i Mevlânâ, Mevlevîliğe intisap eden dervişlerin manen anneleri sayılmış, bu duygularla kendisinin şefkat, merhamet gibi annelik vasfını öne çıkaran özellikleri vurgulanmıştır. Methiyelerde ortak tema Mümine Hatun'a övgü ve onu vesile ederek müşkillerin giderilmesi, iki cihan saadetine erme konulu dualardır. Mümine Hatun için kaleme alınan şiirlerin ilki Midhat Bahârî'ye ait bir kıta, ikincisi Ahmed Remzi Akyürek'in Bir Günlük Karaman Seyahatnamesi ismi ile bilinen kasidesinin beş beyitlik tegazzül bölümü, üçüncüsü Gâlib mahlaslı fakat kim olduğunu tespit edemediğimiz bir şaire ait kaside, dördüncüsü hattat Giritli Şükrü'ye ait bir kasidedir. Mâder-i Mevlânâ'ya şiir yazan dört şairden A. Midhat Bahârî ${ }^{5}$ ve Ahmed Remzi Dede Mevlevî şeyhleri, Gâlib ${ }^{7}$ ve Giritli Şükrü ${ }^{8}$ ise en azından Mevlevî muhibleridir. A. Midhat, Hz. Mevlânâ hakkında kaynak eser mahiyeti taşıyan Sipehsâlâr Risalesi'ni tercüme etmiş, Ahmed Remzi Mevlânâ'dan başlayarak postnişin olan çelebilerin doğum ve ölüm tarihlerini bildiren Tarihçe-i Aktâb adlı eserleriyle Hz. Mevlânâ ve Mevlevîlik tarihine yönelik eserler vermişlerdir.

\section{Dört Manzume}

1- Midhat Bahârî'ye ait kıta: Aruzun mef'ūlü/mefā'îlü/mefā'îlü/fe'ūlün vezni ile yazılan kıtada Mümine Hatun, Hakk'ın 1şığı ve can güneşinin doğduğu yer ve tecelli güneşine benzetilmiştir. Mübalağalı bir ifade ile "Allah değilsin fakat oğlun gibi ilâhî bir nuru dünyaya getirdin." ifadesi ile hem Mevlânâ hem de annesi övülmüştür. Mâder-i Mevlânâ'nın ismi "Mümine Sultan" olarak açıkça yazılmıştır. Kıta tarihsizdir. Hattat

\footnotetext{
${ }^{5}$ Ahmed Midhat Beytur (1875-1971), 20. yüzyıl Mevlevî şeyhi, şair ve edip. Bahariye Mevlevîhânesi'ne mensup olduğu ve şiirlerinde "Bahârî" mahlasını kullandığı için Midhat Bahârî olarak tanınır. Midhat Bahârî' nin tercüme ettiği eserler Sünbülistân (Sünbülistan Şerhi, İstanbul 1325), Ferîdûn-i Sipehsâlâr'ın Risâle'si (Tercüme-i Risâle-i Sipehsâlâr, İstanbul 1331), İbn Kemal'in Risâle fì beyâni'l-vücûd'u (Leâlî-i Meânî̀, İstanbul 1328), Evrâd-ı Mevlevîyye (Münâcât-ı Mevlânâ, İstanbul 1963), İbrâhim Şâhidî'nin Gülşen-i Tevhîd'i (İstanbul 1967) ve Rızâ Kulı Han'ın Mevlânâ'nın Dîvân-1 Kebîr'inden derlediği Dîvân-ı Şemsü'l-hakāyık (Dîvân-ı Kebî̀'den Seçme Şiirler, I-III, İstanbul 1942) Eserleri. 1. Ravza (İstanbul 1314) 2. Güşâ̂r (İstanbul 1328) 3. Mihrâb-ı Aşk 4. Mesnevî Gözüyle Mevlânâ (Işık, 2005, s. 6-7).

${ }^{6}$ Ahmed Remzi Akyürek (1872-1944), 20. yüzyıl mutasavvıf şairlerinden olup Üsküdar Mevlevîhanesi'nin son şeyhi. 1-Manzum Kavâid-i Fârisi, 2-Tuhfetü's-sâimîn, 3-Âyine-i Seyyid-i Sirdân, 4-Mir'ât-ı Zeyne'l-Âbidîn, 5-Münâcât-ı Hazret-i Mevlânâ, 6-Bir Günlük Karaman Seyahatnâmesi, 7-Bergüzâr, 8-Tarihçe-i Aktâb, 9-Gülzâr-ı Aşk, 10-Reh-nümâyı Ma'rifet, 11Tuhfe-i Remzi, 12-Fihrist-i hûb, 13-Üslûb-ı Mergûb, 14-Miftâhü'l-Kütüb ve Esâmi-i Müellifin Fihristi, 15-Zâviye-i Fukarâ, 16-En-nüshatü'ş-şâfiye fî-Tercemeti's-Sohbeti's-Sâfiye 17-Mahbûbül-Ehibbe (Mazıŏ̆lu, 1987, s. 5-11), 18-Mektûbât-l Mevlânâ Celâleddîn (Haksever, 1999, s. 130).

${ }^{7}$ Gâlib mahlaslı ve Gâlib isimli 12 şair tespit edildi. 17. yüzyılda Gâlib (ö. ?), 18. yüzyılda Şeyh Gâlib (1757-1799), 19. yüzyılda Ali Gâlib Efendi (ö. 1844), Abdülhalim Gâlib (ö. 1876), Gâlib Efendi (ö. ?), İzzet Bey-zâde İsmâil Gâlib (1829- ö. ?), Leskofçalı Gâlib (1829/1830-1867), Gâlib Mehmed Said Paşa (1763-1829), Fetvâemînizâde Gâlib Zühdî (ö. 1843), Mehmed Şâkir Gâlib Efendi (1829-1911), 20. yüzyılda Çivici-zâde Gâlib (ö. 1906), Gâlib/Fikrî Niğdeli Mehmed Gâlib Bey (1853-1915) olarak yüzyıllara göre sıralanan bu şairlerin kitap ya da tez olarak çalışılan eserleri arasında Mümine Sultan için yazılan kaside yer almamaktadır. Makalede işlenen kasidenin şairi Gâlib'in kim olduğu bulunamadi.

${ }^{8}$ Giritli Şükrü hakkında 19. yüzyılda yaşayan Mevlevî bir hattat olduğu dışında biyografik bilgi bulunamıştır. Sakıp Sabancı Müzesinde yer alan bir eserinde Cemaziyelevvel 1278/ Kasım- Aralık 1861 tarihi, bu çalışmaya konu olan levhasında ise 1280/ 1863-4) tarihi bulunur (Sakıp Sabancı Müzesi, 2012, s. 301).
} 
Mustafa Halim'in, Midhat Bahârî'ye ait kıtayı talik hatla yazdığı levha kaybolmuştur (Konyalı, 1967, s. 244-245). Kıtanın son iki dizesinin Hattat Mahmut Şahin tarafından yazılmış hali ise Aktekke Camii'nde, Mâder-i Mevlânâ'nın mahfazasındadır.

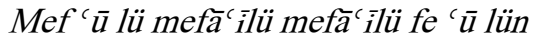

Ey pertev-i Hak maşrık-1 cān şems-i tecellā

Sen Midhat' 'iñi ${ }^{9}$ cevv-i tahayyürlere attı̃

Allāh değilsiñ fakaț ey Mü 'mine Sulțān

Og̉luñ gibi bir nūr-1 ilāhìyi yaratdıñ ${ }^{10}$

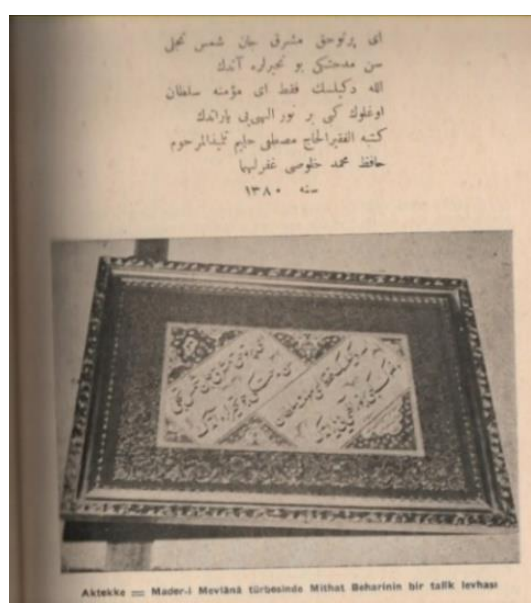

Foto 2: Kayıp Talik Kıtanın İbrahim Hakkı Konyalı'nın Âbideleri ve Kitâbeleri ile Karaman Tarihi, s. 245'ten Çekilmiş Fotoğrafı

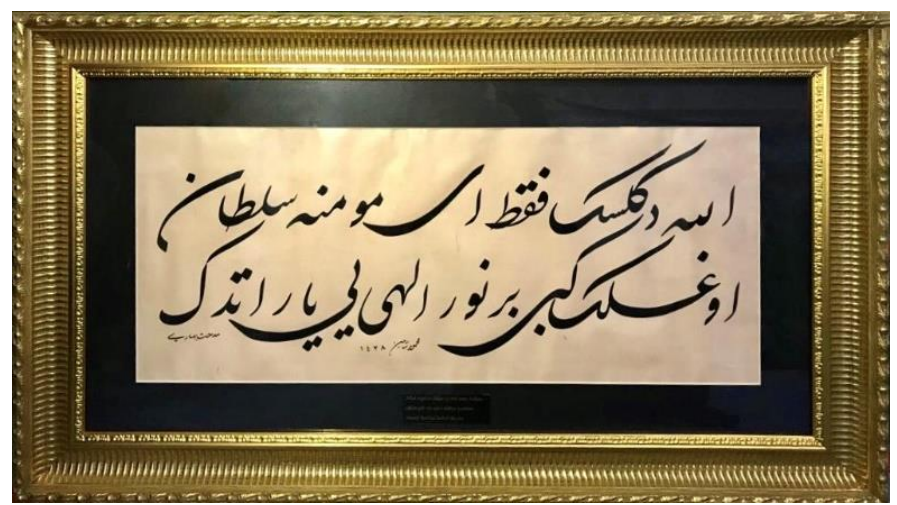

Foto 3: Kıtanın Son Beytinden Talik Levha (Z. K. 2020 Nisan)

2. Ahmed Remzi Dede'nin Bir Günlük Karaman Seyahatnamesi adlı kasidesindeki 15-19. beyitlerde yer alan tegazzül bölümü: 87 beyitten oluşan kaside aruzun fe 'ilâtün /fe'ilâtün/fe'ilâtün/fe'ilün vezni ile yazılmıştır. 06 Mil. Yz., A 7997 nolu eser yedi varaktır. Kapakları kahverengi pandizot bezle kaplı cilt içerisinde, 155x100-125x85 mm, çizgili defter kağıdına rika hat ile yazılmıştır. İkinci ve son sayfası hariç 14 satırlı olan nüsha Hasibe Mazıoğlu bağışıdır, tegazzül kısmı 2b'dedir. Kasidede Ahmed Remzi Dede ve yol arkadaşı Nazif'in Konya'dan Karaman'a yaptığı bir günlük ziyaret ve bu ziyaret esnasında

${ }_{9}^{9}$ Konyalı cevvi kelimesinden önce sehven "bu” kelimesini eklemiştir.

${ }^{10}$ Ey Hakk'ın ışığı, can güneşinin doğduğu yer, tecelli güneşi! Sen Midhat'ini bu hayret boşluklarına attın. Ey Mümine Sultan! Allah değilsin fakat oğlun gibi ilahi bir nuru yarattın. 
yaşadıkları renkli tasvirlerle anlatılmıştır ${ }^{11}$. Kasidenin 7 ve 8 . beyitlerinden Karaman'a gitme nedenlerinin Vâlide Sultan'ı ziyaret etmek olduğu anlaşıllır.

'Arż-1 ḥāl etmek içün Vālide Sulțānımıza

'Āzim-i sūy-ı süveydā-yı Karaman olduk

Kara vapuru ile eyledik țayy-i mekān

Dāhil-i hankāh-ı Vālide Sultạn olduk

Tasvirlerle Karaman Mevlevîhânesi'nin anlatıldığı bölümden sonra lirik ve coşkun bir üslup ile tegazzül kısmına geçilir. Mefâ'îlün/mefâ'îlün/mefâ'̂̂lün/mefâ'îlün vezni ile yazılan tegazzül bölümü beş beyittir. "Aman yâ Hazret-i Mâder" redifli beyitlerde hazineye benzetilen Mümine Hatun'un annelik vasfı ön plana çıkarılmış, rahmet ve şefkati ile iki cihanda kendisinden himmet istenmiştir. Mithat Bahârî'ye ait kıta olduğu gibi Mümine Sultan ve oğlu birlikte övülmüş, tegazzülün ilk beytinde Mevlânâ hikmete, annesi hakikat hazinesine benzetilmiştir. Bir Günlük Karaman Seyahatnâmesi'nde dil muhtevaya göre değişkenlik gösterir. Tegazzül kısmında kasidenin diğer beyitlerine nisbeten daha ağdalı bir dil kullanıldığı, Arapça-Farsça kelimelere yer verildiği görülmektedir. Bu durum ilgili bölümde ele alınan zâta uygun, ona lâyık bir dil kullanma isteğinden kaynaklanıyor olmalıdır. Tegazzülün ardından tahkiyeli bir anlatımla gün içinde yaşananlar anlatılır ve muhteva Konya'ya dönüş yolculuğu olarak değişir. Yazma nüsha tarihsizdir. Hasibe Mazıoğlu tarafından hazırlanan Ahmed Remzi Akyürek ve Şiirleri adlı eserde söz konusu şiirin sonunda hicri 1324 miladi 1906/1907 tarihi bulunmaktadır. ${ }^{12}$ Aşağıda ilgili bölüm verilmiştir:

\footnotetext{
11Kasidenin özeti: “Ahmed Remzi Dede yol arkadaşı Nazif ile birlikte Mâder-i Mevlânâ'yı ziyaret için Karaman’a doğru yola çıar. Konya'dan cuma günü seher vaktinde trenle başlayan seyahat cumartesi gece yarısı Konya'ya tren ile dönmek sureti ile son bulacaktır. Mevlevîhane'ye ulaşan Ahmed Remzi Dede Karaman şeyhine Konya Mevlevîhanesi meşihatinden verilen emri uzatır. Şeyh Efendi memnuniyetini ifade ettikten sonra misafirlerini en güzel şekilde ağırlamaya gayret eder. Yıl 1324/1906-7 günlerden cumadır; sobanın kurulu olması, Yunus Emre Dergâhı'ndan Mevlevîhane'ye düşe kalka gelmeleri ve şiirin ilerleyen bölümlerinde bahsedilen soğuk sebebiyle mevsimin yaz olmadığı anlaşılmaktadır. Az bir istirahat, Valide Sultan'a tazimin arzı, Yunus Emre Dergâhı'nı ziyaretin ardından oldukça acıkan misafirler cuma saatinden önce, Mevlevîhane' de çeşit çeşit yemeklerle ziyafete dönüşen sofrada doyurulurlar. Cuma namazının ardından dervişler toplanır, sema icra edilir, mutriban meşk eder. Karaman nağmesi ile Yunus ilahileri söylenir. Ahmed Remzi Dede Mesnevi-i Şerif'ten okur. Şeyhin müsaadesini alan Dede, eski bir araba ile Karaman'ı gezer ancak gördüğü harap manzaralardan müteessir olur. Dönüş için Karaman şeyhi pek rıza göstermese de geri dönmekte 1srar eden misafirleri için akşam saat 11.00 (24 saatlik sisteme göre yaklaşık olarak 17. 00) trenine bilet alır. Fakat tekerlerin yanması sebebiyle iki saat beklemeleri gerektiği söylenir. Şeyh Efendi misafirlerine yiyecek ve su ikram eder. Ahmed Remzi Dede, şeyhin daha fazla yorulmasını istemez, elini öper; şeyh istasyondan ayrılır. Bekleyiş 03.00'e (yaklaşık 21.00) kadar devam edince yorulan Remzi Dede, şeyhin sözünü dinlemeyip bir gece kalmamaktan duyduğu pişmanlığı dile getirir. 03.14'te (yaklaşık 21.15) tren hareket eder. Karahöyük'ten alınan üç taze yumurta için yazılan üç Farsça beyitin ardından İttihad ve Terakki, Kanun-i Esasi ve gazetelerin üslubu hakkında da yazan Ahmed Remzi Dede, Çumra'dan trene binen Cemal isminde aslen İstanbullu zarif bir memur ile edebiyata dair samimi bir sohbete dalar. Konya'ya ulaştıklarında yorucu geçen yolculuğa eklenen soğuktan oldukça etkilenen ve neredeyse hastalanacaklarını dile getiren Mevlevîler saat yedi (yaklaşık 01.00) sularında, bir otelde istirahate çekilirler. Hemen yatan Nazif, başlarından geçenleri yazmasını arkadaşı Ahmed Remzi'den rica eder ve uykuya dalar. Sekiz (yaklaşık 02.00) sularında şiiri bitiren Ahmed Remzi Dede, ikiye (yaklaşık 08.00) kadar uyur. Uyandıktan sonra, bir arabaya binerek Mevlânâ'nın dergâhına giden Remzi Dede, şiirin eksiklerini tamamlayarak Hazret-i Pîr'e sunmaya niyet eder ve şiir böylece biter." (Koyuncu, 2019, s. 122). Metinde kullanılan ezanî/alaturka saat 1925'te çıkan 697 sayılı kanun ile 24 saatlik sisteme dönüştürülmüştür. Ahmed Remzi Dede'nin Karaman ziyareti hakkında kışı işaret eden beyitleri göz önüne alınarak, takribî bir zaman verildi.

${ }^{12}$ Geniş bilgi için bk. Koyuncu, Z. (2019). “Karaman mevlevîhanesi ve Ahmed Remzi Dede'nin bir günlük Karaman seyahatnâmesi” H. Muşmal, E. Yüksel \& M.A. Kapar (Ed.), Karaman araştırmaları II içinde (s.117-128). Konya: Palet Yayınları.
} 


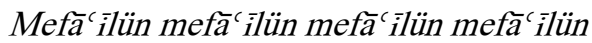

Sen ol kenz-i hakịịatsiñ amān yā Hażret-i Māder

Haḳikat ümm-i hikmetsiñ amān yā Hażret-i Māder ${ }^{13}$

Saña nefh oldı rūḥ-1 pāk-i melā feyz-i Mevlādan

Mücessem rạ̣m u şefkatsiñ amān yā Hażret-i Māder ${ }^{14}$

Merām-1 her dü kevne neyli senden isteriz elbet

Kerem-bahşāa-yı ümmetsiñ amān yā Hażret-i Māder ${ }^{15}$

Cihāna feyż-bahş-1 'aşk-1 Hak necl-i 'azìmiñdir

'Aceb yenbū' -1 raḥmetsiñ amān yā Hażret-i Māder ${ }^{16}$

Nazīf u Remzi rūmāl oldı ḩāk-i pākiñe şimdi

Melāz-1 ehl-i kürbetsiñ amān yā Hażret-i Māder ${ }^{17}$

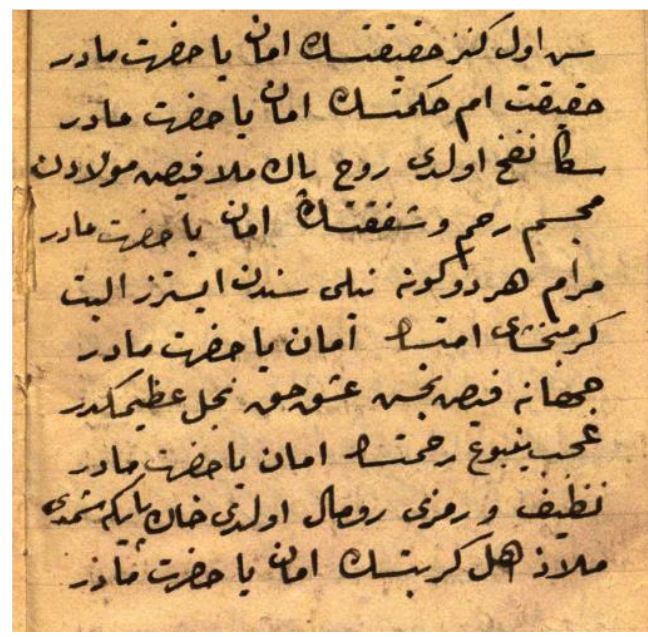

Foto 4: Bir Günlük Karaman Seyahatnâmesi (Ahmed Remzi, 06 Mil. Yz., A 7997, 2b)

3- Gâlib mahlaslı kim olduğu tespit edilemeyen bir Mevlevî şaire ait olan üçüncü manzume ${ }^{18}$ methiye türünde bir kaside olup, 18 beyittir ki bu sayı Mevlevîler için kutsaldır. Başlığı bulunmayan ve aruzun mef'ûlü/mefâ'ilün/mef'ûlü/mefâ'ilün vezni ile yazılan kasidenin redifi “ey Mâder-i Mevlânâ"'dır. Kullanılan rediften memduhun Mümine Hatun olduğu anlaşılır. Kaside baştan sona övgü ifadeleri içerir. Kasidede Mevlevîliğe ait unsur ve terimlerden "mutrib, neyzen, tennure, cân, ihvân, vâlîde-i Pîr", Mümine Hatun'un yol göstericiliğini vurgulayan "rehber, yâver, mürşid", maneviyatına dikkat çeken "gavs, velî"

\footnotetext{
13Sen (öyle bir) hakikat hazinesisin aman ey muhterem anne, gerçekte hikmetin annesisin aman ey muhterem anne! ${ }^{14}$ Mevlânâ'nın feyzinin tertemiz ruhu sana üflendi, rahmet ve şefkatin surete bürünmüş (halisin) aman ey muhterem anne!

${ }^{15}$ Her iki âlemde saadete erme muradını elbet senden isteriz, ümmete ihsan bağışlayansın aman ey muhterem anne! ${ }^{16}$ Dünyaya Hak aşkının feyzini bağışlayan yüce evladındır, nasıl (bir) rahmet pınarısın aman ey muhterem anne! ${ }^{17 S ̧ i m d i ~ N a z i f ~ v e ~ R e m z i ~ a y a g ̆ ı n ı n ~ t o p r a g ̆ ı n a ~ y u ̈ z ~ s u ̈ r d u ̈, ~ d e r t ~ e h l i n i n ~ s ı g ̆ ı n a g ̆ ı s ı n ~ a m a n ~ e y ~ m u h t e r e m ~ a n n e ! ~(K o y u n c u, ~}$ 2019, s. 123). Çeviriler ilgili eserden aynen alındı.

${ }^{18}$ Aynı eserin bir farklı nüshası 16 beyitlik nakıs hali ile İdris Nebi Uysal'a ulaştırılmış ve eserin Karamanlı Mevlevî bir hattat olan Himmet Mercan'a ait olduğu bilgisi alınmış ise de Himmet Mercan'nın yakınlarından edinilen bilgiye göre doğum tarihi H. 1317 (1899-1900) yıllarıdır (Uysal, 2011, s. 102). Manzumeye dört beyit ekleyen Giritli Şükrü ise 19. yy.'da yaşamıştır. Dolayısı ile kronojik olarak şiiri Himmet Mercan yazmış olamaz, fakat istinsah etmiş olması mümkündür.
} 
ve anneliği ve merhametine dikkat çeken "Vâlide -i Pîr, imdât, şefkat" gibi kelimeler bulunur. Beyitlerde iç kafiye mevcuttur.

Bu talik levhanın 18. beytinin sonuna levhayı görüp çok beğendiğini ifade eden Giritli Şükrü nesih hatla 4 beyit eklemiştir. Kasidenin 18 beyit olması Mevlevî adabı açısından dikkat çekicidir. Çünkü, Mevlevîlikte hediyeye nezr ya da niyaz denilir; adak, adanan para, verilen armağan olan nezr sayısı dokuz veya on sekiz olurdu (Top, 2007, s. 181; Gölpınarlı, 2006, s. 46). On sekiz sayısı, Allah'ın 99 isminden biri olan Hayy'ın ebced hesabı ile on sekiz etmesi, Mevlânâ'nın Mesnevî adlı eserinin ilk on sekiz beytini bizzat yazması, kâinatın akl-1 küll, nefs-i küll, dokuz gök, dört unsur (ateş, su, hava, toprak), cemâdât, nebâtât ve hayvânâttan müteşekkil on sekiz varlıktan oluşması, besmeledeki on sekiz sessiz harf, on sekiz bin âlem inancı sebebiyle Mevlevîler için mukaddestir (Aktaran, Koyuncu, 2009, s. 404405). On sekiz sayısının kudsiyyeti etrafında tarikat adabı ve erkân ${ }^{19}$ oluşturulmuştur. Mevlânâ için yazılan methiyelerde de nezr-i Mevlevî’ye özel bir önem verildiği görülmüştür. Eski Türk Edebiyatında Mevlânâ ve Mevlânâ Methiyeleri'nde (Gökalp, 2009) incelenen 41 methiyenin 6's 18 beyit, biri 18 bend, 7'si nezr-i Mevlevî'nin yarısı olan 9, katları olan 36 ve 54 beyitlik şiirlerdir. Osmanlı Şiirinde Mevlânâ Övgüleri ve Mevlevîlik Unsurları' nda (Mermer, vd., 2009) yer alan 783 şiirden sekseninde beyit ve bend olarak nezr-i Mevlevî ve katları kullanılmıştır. Bu seksen manzumenin 26'sı 18 beyit, 10'u 18 bend, 33'ü 9 beyit, 4'ü 9 bend, 7'si 36 ve 54 beyit olarak yazılmıştır.

\section{Mef' $\bar{u}$ lü mefā'ilün mef' $\bar{u}$ lü mefă‘ ilün}

1. Țāli' de Sürreyyāsıñ ey Māder-i Mevlānā Maẓharda çü Zehrāsıñ ey Māder-i Mevlānā̃ ${ }^{20}$

2. Türbeñde Ġażanfersiñ iklimm-i muțalsamsıñ Hüsn-i dile gülşensiñ ey Māder-i Mevlāna $\vec{a}^{21}$

3. Tūbā-yı velāyetsiñ erbāb-1 țarịkatsiñ Hem melce-i bālāsiñ ey Māder-i Mevlāna $\vec{a}^{22}$

4. Raḥmiñde zuhūr itdi çün Hażret-i Mevlānā Hūuri-yi cinān sensiñ ey Māder-i Mevlāna $\bar{a}^{23}$

5. 'Āşsıklara rehbersiñ șādıḳlara yāversiñ Dil mülkine sulțānsıñ ey Māder-i Mevlānãa $\vec{a}^{4}$

6. Sen gavss-ı velāyetsiñ hurrşide müşāabihsiñ Üns-i dile mahremsiñ ey Māder-i Mevlānāa $\bar{a}^{25}$

7. Senden olur imdād her 'ācize bī-mihnet

\footnotetext{
${ }_{19}$ Mevlevî tarikatında matbaha giren derviş on sekiz ayrı vazifeyi yerine getirirdi. Semâ'ya katılan semazen sayısı dokuz veya katları olurdu. Tarikate yeni intisap eden bir derviş, ilk on sekiz gün üstündeki elbiseleri ile çeşitli işlerde çalışır, cübbesinin yakasına on sekiz sıra makine dikişi çekilir, tekbîr edilen sikkesi Mevlânâ'nın sandukası altında on sekiz gün bekletilirdi. Dervişin arkasına değnekle hafif̧ce vurularak yapılan cezalandırmada dokuz ve on sekiz sayısına riayet edilirdi (Ankaravî, 2008, s. 49).

${ }^{20}$ Felekte Süreyyasın, ey Mevlânâ'nın annesi! Görünüşte bir Zehra'sın, ey Mevlânâ'nın annesi!

${ }^{21}$ Türbende muhteşemsin, tılsımlı maneviyatın ile gönül güzelliğinin gül bahçesisin, ey Mevlânâ'nın annesi!

22 Ermişlik tubası, tarikat büyügüüün; hem de yüce bir sığınaksın, ey Mevlânâ'nın annesi!

${ }^{23} \mathrm{~Hz}$. Mevlânâ senin rahminden ortaya çıktığından cennet hurisisin, ey Mevlânâ'nın annesi!

24 Âşıklara rehber, sadıklara yardımcısın; gönül mülküne sultansın, ey Mevlânâ'nın annesi!

${ }^{25}$ Sen velilik kutbusun, güneşe benzeyensin; gönlün ünsüne vakıfsın, ey Mevlânâ'nın annesi!
} 
Şefḳatle mücellāsıñ ey Māder-i Mevlānāa ${ }^{26}$

8. Erbāb-1 zarafetsiñ 'irfāna maḥal sensiñ

İhvāna hidāyetsiñ ey Māder-i Mevlānāa ${ }^{27}$

9. 'Allāme-i 'irfānsıñ keşşāfe-i burhānsıñ

Derdlilere Loḳman'sıñ ey Māder-i Mevlānā"28

10. Hānende-i mutribsiñ neyzenlere demzensiñ

Tennūre pūşānsiñ ey Māder-i Mevlāna $\bar{a}^{29}$

11. Mir'at-1 mücellāsiñ miṣbāhh-1 münevversiñ

Hāl üzre müzeyyensiñ ey Māder-i Mevlāna $\bar{a}^{30}$

12. Pervāz-1 mu'allāsıñ seyyāre-i devrānsı̃̃

Kudsīlere yārānsı̃̃ ey Māder-i Mevlāna $\bar{a}^{1}$

13. Sen nüsh̆a-i berāsiñ mecmu'a-i 'ālemsiñ

Cānlarda mükerremsiñ ey Māder-i Mevlānă $\bar{a}^{32}$

14. Hakikatle dönen sensiñ derd ile yanan sensiñ

Aṣ̣āa ile hemdemsiñ ey Māder-i Mevlāna $\bar{a}^{33}$

15. Gafletten uyanıḳsıñ hạāāta boyanıḳsıñ

Şehbāz-1 hulāyıḷsıñ ey Māder-i Mevlānā ${ }^{34}$

16. Sermāye-i pirānsıñ seyyāle-i erkānsiñ

Maḳbūl-i Hudā'dansıñ ey Māder-i Mevlānāā5

17. Ị̇sān u kerem sensiñ ișār-1 ni`ām sensiñ

Sen Vālide-i Pīrsiñ ey Māder-i Mevlānāāb

18. Mürşīdim olan sensiñ Gäalib'e velì sensiñ

Sen bezm-i elesttensiñ ey Māder-i Mevlānāa ${ }^{37}$

Şükri Giridi geldi bu levhāaya çoḳ bakdı

Gāyetle pesend itdi ey Māder-i Mevlānāä8

Iḥsānda aña ḳılsañ çoḳ kez anı güldürseñ

Íkrāmına gark etseñ ey Māder-i Mevlānāa $\bar{a}^{39}$

Öpdi eşigiñ gitdi bābında ümīd tutdı

Zannı saña çok tutdı ey Māder-i Mevlānă ${ }^{-40}$

\footnotetext{
${ }^{26}$ Aciz kalana senden imdat zahmetsizce olur, şefkat ile parlamışsın, ey Mevlânâ'nın annesi!

27Zarafet sahibisin, irfan kaynağı sensin; (Mevlevî) kardeşleri doğruya yöneltensin ey Mevlânâ'nın annesi!

${ }^{28}$ İrfanı en iyi bilensin, delilleri keşfedensin; dertlilere Hz. Lokman'sın, ey Mevlânâ'nın annesi!

${ }^{29}$ Mutribin söyleyeni, neyzenlerin dem vuranı, tennure kuşanansın, ey Mevlânâ'nın annesi!

${ }^{30}$ Cilananmış aynasın, nurlu kandilsin; hal üzere süslenmişsin, ey Mevlânâ'nın annesi!

${ }^{31}$ Yüce bir yükselişsin, gezegenlerin devranısın; mukaddeslerin dostusun, ey Mevlânâ'nın annesi!

32 Sen (tertemiz bir) nüshasın, âlemin derlenmesisin, canlarda kerem sahibisin, ey Mevlânâ'nın annesi!

${ }^{33}$ Hakikatle dönen sensin, dert ile yanan sensin, sahabiler ile yakınsın, ey Mevlânâ'nın annesi!

${ }^{34}$ Gafletten uyanıksın, hallere boyanıksın, halayıkların yiğidisin, ey Mevlânâ'nın annesi!

${ }^{35}$ Ermişlerin serveti, yolun seyyalesi, Allah'ın makbul gördüklerindensin, ey Mevlânâ'nın annesi!

${ }^{36}$ İyilik ve cömertlik sensin, nimetleri ikram edensin, sen Hazret-i Pîr' in annesisin, ey Mevlânâ'nın annesi!

${ }^{37}$ Mürşidim olan sensin, Gâlib'e veli sensin, sen elest bezmindensin, ey Mevlânâ'nın annesi!

${ }^{38}$ Giritli Şükrü geldi, bu levhaya çok baktı, levhayı çok beğendi, ey Mevlânâ'nın annesi!

${ }^{39}$ Ona da ihsan etsen, onu çok kez güldürsen, ikramına gark etsen, ey Mevlânâ'nın annesi!
}

SEFAD, 2021; (45): 253-270 
Sen boş anı țönderme takșîinine sen baḳma

Bundan girü ag̉latma ey Māder-i Mevlānăat1

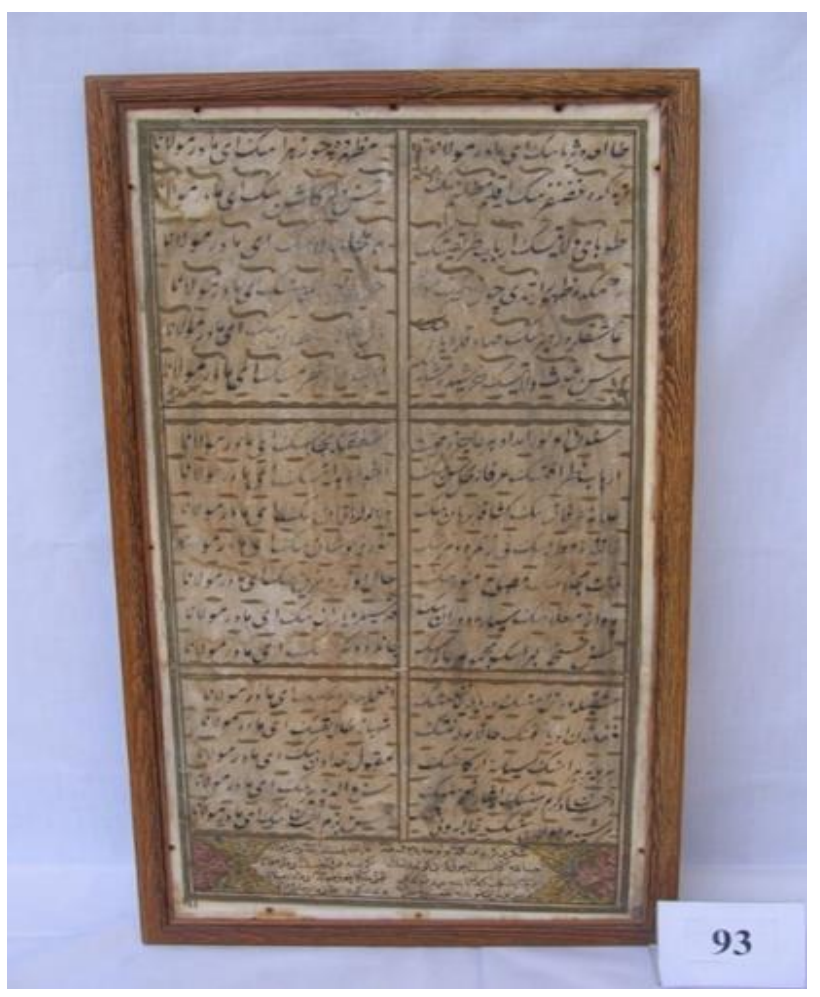

Foto 5: Konya Sahip Ata Müzesinde Bulunan Levha

4. 19 beyitlik dördüncü şiir Hattat Giritli Şükrü42’ye aittir. Mef'ûlü/mefâ'ilün /mef'ûlü/mefâ'ilün vezni ile yazılan bu kasidenin redifi “ey Mâder-i Mevlânâ"'dır. Mısraları ortasında iç kafiye bulunan bu musammat kaside başlıksızdır. Kullanılan rediften memduhun Mümine Hatun olduğu anlaşılır. Kasideye özgü bölümlerden methiye ve dua kısımlarını içerir. Kaside Mümine Hatun'a methiye ile başlamış, Giritli Şükrü'nün memduhun annelik dolayısı ile merhamet duygularına sığınarak hasb-i hâl üslûbu ile hâlini arz etmesi ile devam ettirilmiş misafir olduğundan bahsetmesi ve dua ile bitirilmiştir. Manzume vezin ve redif açısından Gâlib'in yazdığı kasideye nazire özelliği taşımaktadır. Gâlib'in yazdığı kasidede edebî olarak daha güçlü benzetmeler, tamlamalar mevcutken Giritli Şükrü'de ifadelerin daha duygulu şiirin genelinin Arapça-Farsça kelimeler açısından daha sade olduğu görülmüştür. Övgülerde Mâder-i Mevlânâ'nın sırları bilmesi, ihsan ve ikram sahibi olması, kusurları bağışlaması vurgulanmıştır. Nesih hatlı levhanın sol kısmına yatay olarak yazılan üç beyitin bitimine "Denizin ve karanın yaratıcısı onu kutsasın ve

${ }^{40}$ Eşiğini öptü gitti, kapında ümit besledi, senden çok medet umdu, ey Mevlânâ'nın annesi!

${ }^{41}$ Son onu boş gönderme, kusurlarına bakma. Bundan sonra ağlatma, ey Mevlânâ'nın annesi!

42 Giritli Şükrü’nün "Koruyup gözeten Allah'ın bağışlayıcılığına tevekkül ettim" ve "O bağışlayıcıdır, merhamet sahibidir" anlamına gelen Arapça ibareleri iç içe yazdığı Sabancı Müzesindeki levhası için bk. (Sakıp Sabancı Müzesi, 2012, s.301).

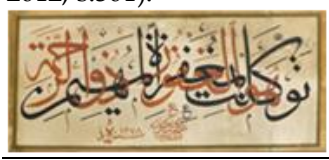


ondan razı olsun. 1863/64" tarihi kaydedilmiştir. Levha çalınma teşebbüsleri sebebi ile şu an Aktekke Camii'nde Mümine Hatun'un kilitli mahfaza bölümünde tutulmaktadır.

\section{Mef ${ }^{`} \bar{u}$ lü mefā'ilün mef' $\bar{u}$ lü mefă‘ilün}

1. [Sen] sırr-1 hakikikatsiñ ey Māder-i Mevlānā Esrāra ki maḥremsiñ ey Māder-i Mevlānā $\bar{A}^{-3}$

2. Taḳdirrde olan esrār ma' lūmuñ olan her-bār Mektūm mı saña āsāar ey Māder-i Mevlānă $\bar{a}^{-44}$

3. Çün çūn u çerā berāyeşs anı ki bilür dervīş Takdìm idemez derpişs ey Māder-i Mevlānā $\bar{a}^{45}$

4. Anı yaradan Hālık anı ki görür lāyık Elbette olur lāḥık ey Māder-i Mevlānāa ${ }^{-46}$

5. Hakkরiñ hükmi vardır ușda mütehayyirdir Hep saña mu' ayyendir ey Māder-i Mevlānā $\bar{a}^{47}$

6. Bu kara yüzim birle geldim saña derdimle Feryād ile āhımla ey Māder-i Mevlānā $\bar{a}^{48}$

7. Kālim saña gūyādır ḥālim saña rü 'yādır Şāniñ ki Sürreyyādır ey Māder-i Mevlānā"-9

8. Sen eyle kerem imdād kesden ki ider bünyād Sen şāh-1 kerem mu'tād ey Māder-i Mevlānăă

9. Kurtar bizi her dā 'im iḥsāniña ḳl kâà ’im Biz bendeñe ey șāhım ey Māder-i Mevlānă $\bar{a}^{5 l}$

10. Sırrımdaki maḥremsiñ remzimdeki a'lemsiñ İhsān idecek sensiñ ey Māder-i Mevlānasaś

11. Māder ḥāli şefkatdir bir daḩi ki rnfkatdir Setr aña ki hāaletdir ey Māder-i Mevlānāa $\bar{s}^{33}$

12. Takșirimi 'afv eyle hem rahm eyle setr eyle İhsānnna gark eyle ey Māder-i Mevlānāas4

13. Sükrī köpeğiñ 'av 'av bābıñda ider ġav gav Amān diyerek ḥav ḥav ey Māder-i Mevlāna ăs5

\footnotetext{
43 Sen hakikat sırrısın, ey Mevlânâ'nın annesi, gizemlerin sırdaşısın, ey Mevlânâ'nın annesi! ${ }^{44}$ Allah'ın yazgısı olan sırlar her defasında sence bilinir, eserler senden gizli mi, ey Mevlânâ'nın annesi! ${ }^{45}$ Derviş neyin ne olduğunu bildiği halde huzurunda (bunu) takdim edemez, ey Mevlânâ'nın annesi! ${ }^{46}$ Onu yaratan Allah lâyık gördüğünden elbette (sırlara) erişen o olur, ey Mevlânâ'nın annesi! ${ }^{47}$ Allah'ın hükmü ile aklın hayret içinde kaldığı ne varsa hepsi senin malumundur, ey Mevlânâ'nın annesi! ${ }^{48} \mathrm{Bu}$ kara yüzümle beraber sana derdimle, feryadımla, âhımla geldim. Ey Mevlânâ'nın annesi! ${ }^{49}$ Sözüm sana söylenen, halim sana (gösterilen) rüyadır, senin şanın Süreyya yıldızıdır. Ey Mevlânâ'nın annesi! ${ }^{50}$ Sen cömertlik, imdat eyle ki (kerem) kişiden temel alır, sen cömertliğine alışılmış olan padişahsın, ey Mevlânâ'nın annesi!

${ }^{51}$ Ey padişahım! Her zaman biz köleni kurtar, ihsanın ile ayakta tut, ey Mevlânâ'nın annesi!

${ }^{52}$ Sırrımdaki sırdaş, remzimdeki bilgisin, cömertlik edecek sensin, ey Mevlânâ'nın annesi!

${ }^{53}$ Anne hali şefkat bir de yumuşaklıktır, örtü ona keyfiyettir, ey Mevlânâ'nın annesi!

${ }^{54}$ Kusurumu affet, hem merhamet et hem ört, ihsanına gark et, ey Mevlânâ'nın annesi!
}

SEFAD, 2021; (45): 253-270 
14. İhsānıña nāzırdır in ‘āmıña ḥāżırdır

Gitmekde müsāfirdir ey Māder-i Mevlānāa ${ }^{6}$

15.Kalıpca eger gitse kalbice ebed kalır

Bābıñda müdām umsa ey Māder-i Mevlānă $\bar{a}^{7}$

16. Bu gūne 'ināyet ḳ1 hem aña himāyet ḳ1

Yardım aña çok itgìil ey Māder-i Mevlānă $\bar{a}^{8}$

17. Mah̆ūum ḳomağıl bir ān emānım olan her ān

Íhsānıña ḳ1 seyrān ey Māder-i Mevlānă $\bar{a}^{9}$

18. Zāhirde vü bātında dünyā vü āhiretde

Íhsānıña şermende ḳıl Māder-i Mevlānă ${ }^{60}$

19. Ey Māder-i Mevlānā ey Māder-i Mevlānā

Koma bizi nā-bīnā ey Māder-i Mevlānăơl

'Aleyhā taḳișu Hāliḳu'l-baḥr ve'l- berr ve rażiye anhā rabbunā sene 1280

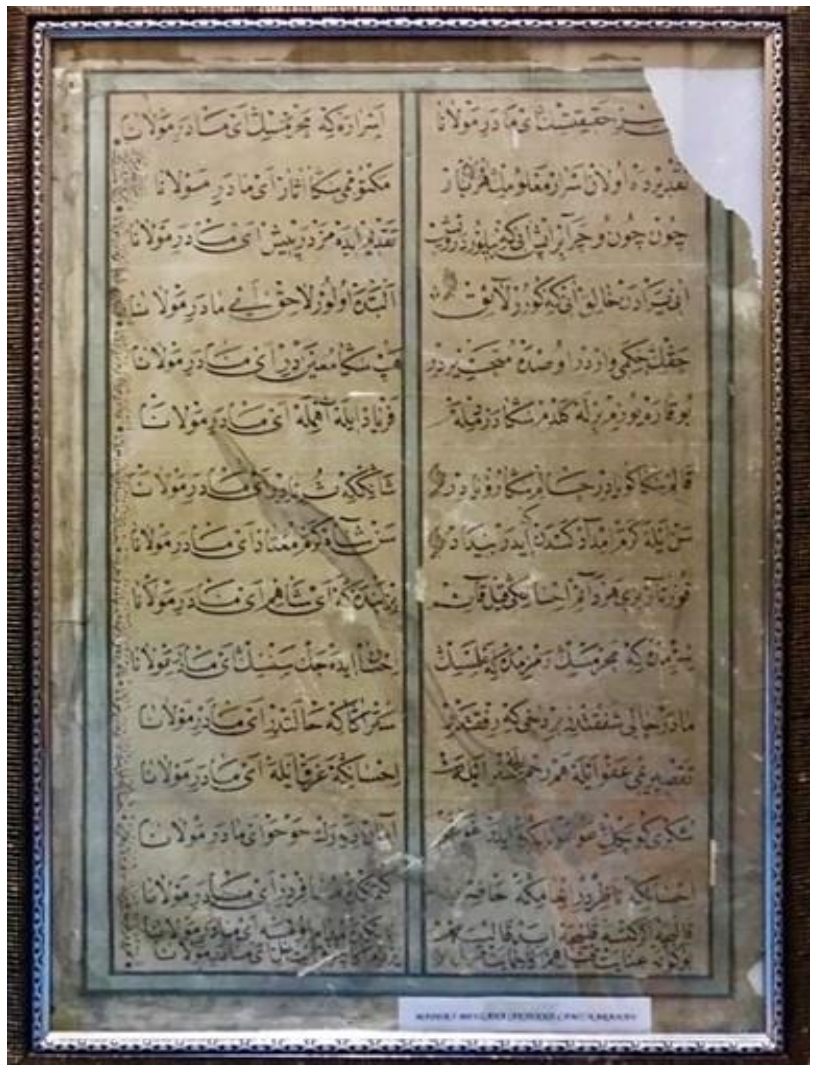

Foto 6: Aktekke Camii Mâder-i Mevlânâ Mahfazasındaki Levha (Z.K. 2020 Nisan).

${ }^{55}$ Ey Mevlânâ'nın annesi! Şükrü köpeğin kapında (ağlaya ağlaya) inler, aman dileyerek havlar.

${ }^{56}$ Bağışını beklemekte, yardımın (için) huzurundadır, gitmek üzere misafirdir, ey Mevlânâ'nın annesi!

${ }^{57}$ Kalıp olarak gitse bile kalp olarak ebedi kalır, kapından daima umar, ey Mevlânâ'nın annesi!

${ }^{58}$ Bunun gibi lutfet, hem onu koru, yardımını çok çok et, ey Mevlânâ'nın annesi!

${ }^{59}$ Ey sığınağım olan! Bir an olsun mahrum bırakma, ihsanına göz gezdirme yeri kıl, ey Mevlânâ'nın annesi!

${ }^{60}$ Görünüşte ve gizlide dünyada ve ahirette (onu) iyiliğinle utandır, ey Mevlânâ'nın annesi!

${ }^{61}$ Ey Mevlânâ'nın annesi, ey Mevlânâ'nın annesi! Bizi görensiz bırakma, ey Mevlânâ'nın annesi! 


\section{SONUÇ}

Mevlânâ şair ve mutasavvıf kimliği, Mevlevî kültürü de edebî malzeme olarak divan şiirinde yer edinmiştir. Mevlânâ ve Mevlevîlik ile ilgili pek çok unsur altı yüz yıl boyunca başta Mevlevî şairler tarafından olmak üzere kullanılmış, Mevlânâ methiyeleri müstakil çalışmaların konusu olmuştur. Kabri Karaman'da Aktekke Camii'nde bulunan Mevlânâ'nın annesi Mümine Hatun da benzer bir ilgi görmüş, Mevlevîlerin manevî annesi sayılmış ve kendisi için de şiirler kaleme alınmıştır. Mevlevîler veya Mevlevî derviş ve şeyhleri ziyaretleri esnasında ya da sonrasında Mümine Hatun'a olan hürmetlerini şiirle ifade etmişlerdir. Bu şairlerden Ahmed Mithat Beytur, Ahmed Remzi Akyürek 20. yüzyıl Mevlevî şeyh ve edipleri, kim olduğu tespit edilmeyen Gâlib mahlaslı şair ise en azından Mevlânâ muhibbidir. Makalede işlenen dört manzumenin üçü hüsn-i hat levhası şeklindedir. 19. yüzyılda yaşamış Mevlevî bir hattat olan Giritli Şükrü, Gâlib'in levha olarak gördüğü kasidesini çok beğenmiş, kendisi de aynı vezin ve redifle bir kaside yazıp levhalaştırmıştır. Mevlevîlik tarikatında sanatın iki kolu şiir ve hüsn-i hattın birbirini besleyerek ilerlediği bilinir. Mevlevîliğin hayatın her alanında uygulanan kendine has adab ve erkanı vardır. Mevlevîliğin büyükleri, şeyhleri kabirleri başında anılır, bir dergâha eli boş girilmezdi. Bu adab gereği Mevlânâ'nın annesinin manevi huzuruna gelen Mevlevî şairler de şiirlerini hediye edip niyazda bulunmuşlardır. 18 sayısı Mevlevî şiarında mukaddestir. Bu sebeple Gâlib, nezr-i Mevlevî olan 18 beyitle hürmetini ifade etmiş̧, Giritli Şükrü bir fazlası olan 19 beyit ile bu geleneğe yaklaşmak istemiştir.

Manzumeler biçimsel açıdan bir kıta, kaside içindeki bir gazel (tegazzül) ve iki kasidedir. Muhteva açısından incelendiğinde şiirlerin tamamında Mevlânâ'nın annesinin çeşitli sıfatlar ve benzetmeler ile övüldüğü, kendisinden himmet ve feyiz istendiği görülmüştür. Muhtevada dikkati çeken bir diğer unsur yapılan benzetmelerin, övgülerde kullanılan kelime kadrosunun Mevlânâ methiyeleri ile benzerliğidir. Makalede Mümine Hatun'a yazılan methiye tarzındaki manzumeler derli toplu hale getirilerek ilim dünyasının dikkatine sunulmuştur. Araştırma esnasında çıarılan bir diğer sonuç Karaman Mevlevîhanesi ve içindeki teberrükat eşyasının iyi korunamadığı; kayıplar, çalıntılar sebebiyle günümüze çok az hatıra kaldığı, elde kalan bu eşyaların bazılarının Konya Sahip Ata Müzesi'nde bulunduğudur.

\section{SUMMARY}

Founder of Mevleviyeh, one of the most important and widespread sects of the Islamic world, Hz. Mevlânâ (d.1273) spent his first youth in Karaman. Due to the fact that the graves of the mother of Mevlânâ and important family members are in Aktekke Mosque in Karaman, the city has a special value for the Mevlevî. Karaman (Lârende) Mevlevî Lodge still maintains its importance for the Mevlevî. The commemoration ceremonies of Mevlânâ, which are held every year, started in the presence of his mother. Biographical information about Mümine Sultan, who gave birth and raised a distinguished scholar like Mevlânâ, is limited with the marriage, the birth of her children and date of her death. The compensation of "Mâder-i Mevlânâ" means "the mother of Mevlânâ". Mevlevî people also remember Mümine Hatun with expression of honor such as Mâder-i Mevlânâ, Mâder Sultan, Valide Sultan.

Mevlevîyeh had its own rules and conventions and these rituals were practiced in all areas of life, from table manners to dressing, from visiting graves to giving gifts. The elders

SEFAD, 2021; (45): 253-270 
and sheikhs of Mevlevîyeh were commemorated by their graves, and did not enter a Dervish Lodge empty-handed. Karaman Mevlevî Lodge was among the most important places to visit. Since it was necessary to give a gift even with a "green leaf" according to the Mevlevî manners, the compassion and reverence to Mevlânâ, who influenced classical Turkish poetry for 600 years, was shown by poets from his school through poetry. These poems, the subject of which is Mevlânâ's praises, constitute a whole in itself. In these praises, the close circle and family of Mevlânâ were also remembered with respect. The similar internal and external structures of the praises written to the mother of Mevlânâ and the praises with the repeated word "yâ Hazret-i Mevlânâ" are remarkable. In the poems in question, Mümine Hatun was loved with respect, just like her son, and was praised with the words used for her son.

These poems, which are the subject of the article, are composed of a stanza belonging to the Mevlevî sheikh and preacher Ahmet Midhat Beytur (d. 1971), a 5-couplet tegazzul as part of the One-Day Travel Book of Karaman belonging to one of the late Mevlevî sheikhs and poets Ahmed Remzi Akyürek (d. 1944), an 18-couplet ode belonging to a Mevlevî poet with the pseudonym Gâlib (d. ?) and a 19-couplet ode belonging to the Calligrapher Cretan Şükrü (d. ?). The common content of these poems, which have been compiled and brought to the attention of the world of science, are the praises of Mümine Hatun and the prayers made on her occasion. The number of couplets, which is 18 in the ode of Gâlib, has a remarkable aspect in terms of Mevlevî manners. This number was considered sacred in Mevlevîyeh because Hz. Mevlânâ wrote the first 18 couplets by himself and was referred as "nezr-i Mevlevi". This number was observed in the manners of the sect, from the division of labor to gift giving, from punishment to the number of whirling dervishes.

In Mevlevîyeh, great importance was attached to the fine arts, and the Mevlevî dervishes were also engaged in music, painting and calligraphy besides Sufism. While the naskh calligraphy ode belonging to the Cretan Şükrü and the last two lines of Ahmed Midhat's stanza written by Calligrapher Mahmut Şahin are in the locked case of Mader-i Mevlânâ today, the talik calligraphy plate which belongs to Gâlib, is in the Konya Sahip Ata Museum. At the end of our research, it was concluded that the Karaman Mevlevi Lodge, which turned into a mosque after the closure of the lodges, was damaged for such reasons as neglect and wrong municipal activities. Also it was found that the tabarrukat items inside it have not survived due to various reasons such as losses, stealing and carelessness. 
Makale Bilgileri

Etik Kurul Karart:

Katılımo Rızası:

Mali Destek:

Çıkar Çatışması:

Telif Haklart:
Etik Kurul Kararından muaftır.

Katılımcı Yok

Çalışma için herhangi bir kurum ve projeden mali destek alınmamıştır.

Çalışmada kişiler ve kurumlar arası çıkar çatışması bulunmamaktadır.

Çalışmada kullanılan görsellerle ilgili telif hakkı sahiplerinden gerekli izinler alınmıştır.

Article Information

Ethics Committee Approval:

Informed Consent:

Financial Support:

Conflict of Interest:

Copyrights:
Exempt from the Ethics Committee Decision.

No participant

No financial support from any institution or Project

No conflict of interest.

The required permissions have been obtained from the copyright holders for the images and photos used in the study. 


\section{KAYNAKÇA}

Aça, M., Gökalp H. \& Kocakaplan, İ. (2011). Başlangıçtan günümüze Türk edebiyatında tür ve şekil bilgisi. İstanbul: Kesit Yayınları.

Ahmed Remzi. Bir günlük Karaman seyahatnamesi. Milli Kütüphane Yazmalar. 06 Mil. Yz. A 7997, 1b-7b.

Aktaş, H. (2008). Çağdaş bir mevlevî havarisi Arif Nihat Asya'da Mevlânâ imaji. Adıyaman Üniversitesi Sosyal Bilimler Enstitüsü Dergisi 1(1) 43-54, Erişim adresi: https://dergipark.org.tr/tr/pub/adyusbd/issue/1402/16582.

Asya, A. N. (1967). Rubâiyyat-ı Ârif IV kova burcu. Ankara: Defne Yayınları.

Can, Ş. (1995). Mevlâna hayatı şahsiyeti fikirleri. İstanbul: Ötüken Neşriyat.

Çelebi, C. (2001). Hazret-i Mevlânâ. Konya: Konya Valiliği İl Kültür Müdürlüğü.

Evliya Çelebi (2012). Seyahatnâme. S. A. Kahraman \& Y. Dağlı, (Haz.) 3. Kitap C. 1, İstanbul: Yapı Kredi Yayınları.

Gökalp, H. (2009). Eski Türk edebiyatında Mevlânâ ve Mevlânâ methiyeleri. İstanbul: Kriter Yayınları.

Gölpınarlı, A. (2006). Mevlânâ'dan sonra mevlevîlik. İstanbul: İnkılap Yayınevi.

Gülcan, D. A. (1975). Karaman mevlevîhânesi mevlevîlik ve Karamanlı mevlevî velileri. Karaman: Doğuş Matbaası.

Haksever, A. C. (1999). Ahmed Remzi Akyürek hayatı, eserleri ve tasavouf (Yüksek Lisans Tezi). Erişim adresi: https://tez.yok.gov.tr/UlusalTezMerkezi/tezSorguSonuc Yeni.jsp.

Işık, E. (2005). Midhat Bahârî. İslâm ansiklopedisi (C.30, s. 6-7). İstanbul: Türkiye Diyanet Vakfı Yayınları.

İsmail Rüsûhî Ankaravî (2008). Mesnevî́nin sırrı dibâce ve ilk 18 beyit şerhi. S. Ceyhan\& M. Topatan (Haz.), İstanbul: Hayy Kitap.

Konyalı, İ. H. (1967). Âbideleri ve kitâbeleri ile Karaman tarihi. İstanbul: Baha Matbaası.

Koyuncu, Z. (2009). Hüsn ü Aşk'ta on sekiz sayısı üzerine. Turkish Studies, (4/7), 401-423, doi: http://dx.doi.org/10.7827/TurkishStudies.913

Koyuncu, Z. (2019). Karaman mevlevîhânesi ve Ahmed Remzi Dede'nin bir günlük Karaman seyahatnâmesi. H. Muşmal, E. Yüksel \& M.A. Kapar (Ed.), Karaman araştırmaları II içinde (s.117-128). Konya: Palet Yayınları.

Mazıoğlu, H. (1987). Ahmed Remzi Akyürek ve şiirleri. Ankara: Sevinç Matbaası.

Mermer, A., Hidayetoğlu, A. S., Erdoğan \& M., Koç Keskin, N. (2009). Osmanlı şiirinde Mevlânâ ve mevlevîlik unsurları. Ankara: Türkiye Diyanet Vakfı.

Sahih Ahmed Dede (2003). Mecmuatü't- tevarihi'l- mevlevîye mevlevîlerin tarihi. C. Zorlu (Haz.), İstanbul: İnsan Yayınları.

Sakıp Sabancı müzesi kitap sanatları ve hat koleksiyonu (2012). Erişim adresi: https://sakipsabancimuzesi.org/sites/default/files/publication/pdf/Kitap_Sanatlari_Hat. pdf Erişim tarihi: 02.02.2020

Tanrıkorur, B. (2001). Karaman Mevlevîhânesi. İslâm ansiklopedisi (C.24, s. 447-448). İstanbul: Türkiye Diyanet Vakfı Yayınları.

Top, H. H. (2007). Mevlevî usûl ve âdâbı. İstanbul: Ötüken Yayınları.

Uysal, İ. N. (2011, Kış). Mâder-i Mevlânâ'ya kaside. İmaret, 100-102. 